\title{
Mesleki İlgi Ölçeğinin Geliştirilmesi ve Uygulanması
}

\author{
Feyzi Kaysi \\ İstanbul Üniversitesi-Cerrahpaşa, Teknik Bilimler Meslek Yüksekokulu, İstanbul. \\ ORCID: F. Kaysi (0000-0001-6681-4574)
}

\begin{abstract}
Özet
Üniversite öğrencilerinin öğrenim gördükleri programı tercih etme nedenleri arasında, ilgili programa yönelik ilgileri etkili olabilmektedir. Bu çalışmanın amacı, üniversite öğrencilerinin ve mezunlarının mesleki ilgi düzeylerini belirlemektir. Çalışma nicel yöntemle gerçekleştirilmiştir. Çalışmada verileri elde etmek amacıyla Mesleki illgi Ölçeği geliştirilmiş ve uygulanmışır. Ölçeğin geliştirilmesi boyutunda 254 katılımcı yer almıştır. Ölçek dört boyut ve 19 maddeden oluşmaktadır. Ölçeğin uygulanması aşamasında 296 katılımcı çalışmaya dahil edilmiştir. Çalışmada katılımcıların mesleki ilgilerinin yüksek düzeyde olduğu sonucuna ulaşılmışır. Üniversite tercihlerinde mesleki ilgilerini ön planda tuttukları anlaşılmaktadır. Ayrıca bireylerdeki mesleki ilginin oluşmasında yaşantıların etkili olduğu belirlenmiştir. Mesleki ilginin yaşa ve programa bağlı olmadan mezuniyet sonrasına da yansıdığı sonucu elde edilmiştir. Çalışmanın önerileri arasında, ölçeğin farklı zamanlarda uygulanması ile öğrencilerin mesleki ilgi düzeylerindeki değişimin gözlenmesi yer almaktadır.
\end{abstract}

Anahtar kelimeler: mesleki ilgi; mesleki ilgi düzeyi; ölçek geliştirme; üniversite öğrencileri

\section{Development and Implementation of the Professional Interest Scale}

\begin{abstract}
Professional interest of individuals can affect university selection. The purpose of this study is the investigation of professional interest levels of university students and graduates. The study was carried out with quantitative techniques. Professional Interest Scale was developed and implemented to collect data in the study. The scale consists of four dimensions and 19 items. During the implementation phase of the scale, 296 participants were included in the study. In the study, the participants' professional interests were at high level. It is understood that they prioritize their professional interests in university selection. In addition, it has been determined that experiences are effective in creating professional interest in individuals. It was concluded that professional interest is reflected after graduation regardless of age and professional program. Among the suggestions of the study are observing the change in the professional interest levels of the students by ensuring that the scale is implemented at different times.
\end{abstract}

Keywords: scale development; university students; professional interest; professional interest level.

\section{GiRiş}

Bireylerin üniversite veya öğrenim görecekleri program tercihleri esnasında göz önünde bulundurdukları etkenlerden bir tanesi ilgidir. İlgi kısaca, bireylerin meyilleri şeklinde ifade edilebilir. Bu meyillerin gerçekleștirilmesi sonrasında bireylerin yaşamları da etkilenebilmektedir. Diğer bir ifade ile ilgi, bireylerin yaşantılarını ve çevreleriyle olan etkileşimlerini etkileyen bir kavramdır (Ion, Nye ve Iliescu, 2019; Yaman, Gerçek ve Soran, 2008). Aynı zamanda bireylerin davranışlarını, öğrenme hedeflerini ve başarılarını da etkilemektedir (Pohlhausen, 2005). Bu nedenle bireylerin yapacakları tercihlerde, ilgilerinin etkisiyle yaşamlarının sonraki aşamaları

*Yazışma Adresi / Address for Correspondence:

F. Kaysi, Email: fkaysi@iuc.edu.tr

Geliş Tarihi / Received Date: 11.02.2021

Kabul Tarihi / Accepted Date: 04.03.2021

Doi: $10.26701 /$ uad. 878426 da şekillenebilmektedir. Çünkü ilginin oluşmasında yaşantıların etkisi oldukça yüksektir (Özgüven, 2000). Bu bakımdan üniversite öğrencilerinin öğrenim süresince yaşantıları, tercih ettikleri mesleğe yönelik ilgilerini etkilemektedir. Bireylerin, yaşamlarının sonraki aşamalarını etkileyebilecek en önemli kararlardan biri, meslek seçimi esnasında ortaya çıkmaktadır (Atli ve Keldal 2017). Bazı durumlarda yaşanan olumsuz durumlar bireyleri mesleki ilgi açısından olumsuz etkilerken, bazı durumlarda bireylerin mesleki ilgileri olumlu şekilde değişebilmektedir. Mesleki ilgi, bir bireyin belirli bir etkinliği, akademik konuyu veya mesleği ne ölçüde sevdiği olarak tanımlanmaktadır (Sheu ve diğ., 2010). Bu bakımdan mesleki ilgi, üniversite öğrenimi süresince birçok karar alma durumunda etkili olabilmektedir (Yaman, Gerçek ve Soran, 2008). Bireylerin öğrenim gördükleri programa yönelik ilgilerinin belirlenmesi önem arz etmektedir (Dikmen ve Tuncer, 2018). Özellikle meslek seçimi sürecinde bireylerin ilgi, yetenek ve beklentilerini göz önünde bulundurarak tercih yapması önem 
taşımaktadır (Polatcı ve Gültekin, 2019). Aksi takdirde, yaşantılar sonucu beklentilerin karşılanmaması durumunda bireylerin mesleki ilgileri azalabilmektedir. Bu durum mezunların istihdamında da olumsuzluklara neden olabilmektedir. Çünkü işe alım süreçlerinde bireylerin istihdam olacakları işyerine uygun beceri ve yeteneklere sahip olması beklenmektedir (Sekiguchi, 2004). Bunu sağlamanın yollarından birisi de, bireylerin mesleki ilgilerinin beklenen düzeyde olması ile gerçekleşebilir. $\mathrm{Bu}$ sayede bireylerin mesleki uygunlukları mesleki ilgileri ile ilişkilendirilebilir. Diğer bir ifadeyle, mesleklerin ilgi düzeyi yüksek bireylerce gerçekleştirilmesi, niteliği ve memnuniyeti arttırabilir (Yaman, Gerçek ve Soran, 2008). Bu sayede istihdam olacak bireyler ve işverenlerdeki memnuniyet de artabilir.

Mesleki ilgilerin tanımlanmasında üç temel özellik öne çıkmaktadır. Bunlar mesleki ilgilerin bireysel özellikler olduğu, mesleki ilgilerin bireyin etkinlik tercihini yansıttığı ve mesleki ilgilerin bireyde itici güç veya motivasyon kaynağı olduğu şeklindedir (Rounds ve Su, 2014). Bu özelliklerin bireylerin yaşantılarını doğrudan etkilediği düşünüldüğünde, bireylerin yaşamlarının en önemli etkenleri arasında mesleki ilgilerin yer aldığ ${ }_{1}$ ifade edilebilir. Mesleki ilgiler iş yaşamında da etkili olabilmektedir. Mesleki ilgi ve öz-yeterlik algıları mesleki seçim sürecini etkileyen en önemli faktörler olarak görülmektedir (Baker, Larson ve Seipel, 2019; Larson, 2012). Bu kavramlar ile bireylerin çevreleri hakkında karar verdikleri anlaşılmaktadır. İlgiler, bireylerin belirli faaliyetlere ve çevrelere yakınlaşmalarında veya onlardan uzaklaşmalarında yönlendirici bir role sahiptir (Larson, Pesch, Bonitz, Wu ve Werbel, 2014). Aynı zamanda ilgilerin eğitim ve kariyer hakkında karar vermede en önemli faktör olduğu (Tang, 2009) ve bu çerçevede eğitim ve kariyer seçimlerinin öngörüldüğü sonucuna ulaşılmıştır (Elsworth, Harvey-Beavis, Ainley ve Fabris, 1999). Mesleki ilginin bireylerin iş hayatındaki etkileri de dikkat alınmalıdır. Bireylerin mesleki ilgilerinin bilinmesi, iş performansını tahmin etmede yardımcı olabilir (Van Iddekinge, Roth, Putka ve Lanivich, 2011). Bu sayede bireylerin istihdamları hakkında daha iyi kestirimler yapılabilir.

Mesleki ilgiyi etkileyen başka etkenler de bulunmaktadır. Kültürel etkenlerin mesleki ilgileri etkilediği görülmüştür (Ott-Holland, Huang, Ryan, Elizondo ve Wadlington, 2013). Aynı zamanda okul, aile ve iş gibi çevresel etkilerle mesleki ilgilere yönelik cinsiyet ve yaşa bağlı beklentiler üzerinden kimlikler oluşturulur (Low ve Rounds, 2007). Mesleki ilgi boyutlarında, erkeklerin daha yüksek düzeyde gerçekçi ve araştırmacı ilgileri ve kadınların da daha yüksek düzeyde sanatsal ve sosyal ilgileri vardır (Su, Rounds ve Armstrong, 2009). Mesleki ilgiler, bazen diğer ilgileri de olumlu şekilde etkileyebilmektedir (Perera ve McIlveen, 2018). Bireylerin mesleki ilgilerinden tatmin olmaları halinde, yaşamlarının diğer süreçlerinin olumlu şekilde etkilenebileceği ifade edilebilir. Aynı zamanda mesleki ilgiler mesleki arzuları da ortaya çıkarır
(Bergmann ve Eder, 2005). Bu sayede bireylerin mesleklerinden memnun olma düzeyleri artabilir. Stajlardaki mesleki deneyimler, bireylerin mesleki çevrelerinin oluşmasını etkiler (Neuenschwander, Hofmann, Jüttler ve Schumann, 2018).

Zamanla bireylerdeki mesleki ilgiler değişebilmektedir. Bireylerin mesleki ilgi düzeyleri ergenlik döneminde az da olsa artma eğilimindedir (Tracey, Robbins ve Hofsess, 2005). Bu eğilim yetişkinlik dönemlerinin ortalarına kadar devam edebilmektedir (Donnay, Morris, Schaubhut ve Thompson, 2005). Fakat mesleki ilgideki kararlılık 18 ve 22 yaşları arasında en yüksek seviyeye ulaşır (Low, Yoon, Roberts ve Rounds, 2005). Bu kararlılığın oluşmasında, lise dönemlerinde oluşan mesleki ilginin üniversitedeki deneyimlerle şekillendiği anlaşılabilir. Üniversite öğrencilerinin yaş grupları incelendiğinde, bireylerin mesleki ilgileri bu dönemlerde büyük oranda şekillendiği ifade edilebilir. Bu nedenle üniversite öğreniminin bireylerin mesleki ilgilerine karar vermede en önemli zaman dilimlerinden birisi olduğu belirtilebilir. Üniversite öğrencileri, öğrenimlerini bir meslekle ilgili bilgi, beceri ve davranışlarını kazanmak amacıyla gerçekleştirmektedirler. Bu kazanımları besleyen en önemli hususlar arasında mesleğe yönelik kișinin sahip olduğu ilgi düzeyidir. Öğrencilerin üniversite öğrenimleri sürecindeki deneyimleri mesleki ilgilerini etkileyebilmektedir. Öğrencilerin üniversite öğrenimlerindeki mesleki ilgi düzeylerinin ölçülmesi, bireylerin öğrenim gördükleri mesleğe yönelik ilgilerini ve mesleki ilgilerdeki değişimleri de ortaya çıkarabilir. Bu çalışmanın amacı, üniversite öğrencilerinin ve mezunların mesleki ilgilerini ölçmek amacıyla ölçek geliştirmek ve bu ölçeği uygulayarak bireylerin mesleki ilgi düzeylerini belirlemektir. $\mathrm{Bu}$ amaç doğrultusunda üniversite öğrencileri ve mezunların mesleki ilgi düzeylerinin cinsiyet, mezun olunan lise türü, sınıf, statü, yaş, çalışma durumu ve öğrenim görülen program değişkenlerine göre anlamlı farklılık gösterme durumları incelenecektir. Böylece belirlenen ölçek boyutları için öğrencilerin mesleki ilgi düzeylerin belirlenmesi ve mesleki ilgi düzeylerinin değişimi yorumlanabilir.

\section{YÖNTEM}

Çalışma nicel veri toplama yöntemiyle gerçekleştirilmiştir. Bu kapsamda çalışma betimsel tarama modelinde gerçekleştirilmiştir. Tarama modeli belirlenmiş bir gruptaki bazı özelliklerin ifade edilmesi amacıyla verilerin toplanmasını olarak ifade edilmiştir (Büyüköztürk, Çakmak, Akgün, Karadeniz ve Demirel, 2008). Bu sayede çalışma grubunun daha iyi ifade edilebileceği düşünülmektedir. Çalışma Mesleki İlgi ölçeğinin geliştirilmesi ve geliştirilen ölçeğin uygulanması şeklinde iki boyutta tamamlanmıştır. Ölçeğin geliştirilmesi aşamasında SPSS 22.0 paket programıla açımlayıcı faktör analizi ve Lisrel paket program ile de doğrulayıcı faktör analizi süreçleri tamamlanmıştır. Ölçeğin uygulanması aşamasında elde 
edilen veriler, SPSS ile analiz edilmiștir.

\section{1. Ölçeğin Geliştirilmesi}

Ölçek geliştirme çalışmalarında İstanbul'daki bir devlet üniversitesinde öğrenim gören 254 katılımcı yer almıştır. Alanyazın taranması ve öğrencilerle yapılan informel görüşmeler sonrasında ölçek madde havuzu için 27 potansiyel madde belirlenmiștir. Bu maddeler, biri eğitim programları diğeri mesleki eğitim alanında uzman iki öğretim üyesinin görüşlerine sunulmuştur. Öğretim üyelerinin beyan ettikleri görüşler doğrultusunda iki madde potansiyel ölçek havuzundan çıkarılmıștır. Faktör analizi çalışmaları 23 madde ile sürdürülmüştür. Faktör analizi esnasında 40'tan fazla madde içermeyen ölçeklerde 200 bireylik örneklem büyüklügünün yeterli olduğu belirtilmiştir (Comrey, 1988). Aynı zamanda, çalışılacak örneklemin madde sayısının beş veya 10 katı kadar olması da beklenmektedir (Büyüköztürk, 2002;

Tablo 1. Ölçek Geliştirme Sürecinde Doğrulayıcı Faktör Analizi Sonuçları

\begin{tabular}{|c|c|c|c|c|}
\hline \multirow{2}{*}{ Madde } & \multicolumn{4}{|c|}{ Faktörler ve Madde Yükleri } \\
\hline & $\mathrm{MH}$ & KG & MSF & MBÖ \\
\hline M21: Mesleğimle ilgili uygulamaları yapabilirim. & .778 & & & \\
\hline M13: Mesleğime yönelik yeterliliklere sahibim. & .764 & & & \\
\hline $\begin{array}{l}\text { M8: Mesleğimdeki uygulamalar, yeteneklerime } \\
\text { uygundur. }\end{array}$ & .669 & & & \\
\hline $\begin{array}{l}\text { M7: Mesleğimde karşılaştığım zorlukların } \\
\text { üstesinden gelebilirim. }\end{array}$ & .645 & & & \\
\hline $\begin{array}{l}\text { M15: Mesleki alan bilgimin yeterli olduğunu } \\
\text { düşünüyorum. }\end{array}$ & .607 & & & \\
\hline M3: Bu mesleğe uygun olduğumu düşünüyorum. & .583 & & & \\
\hline M19: Mesleğimden memnunum. & .545 & & & \\
\hline $\begin{array}{l}\text { M14: Mesleğimle ilgili yazılımları sürekli takip } \\
\text { ederim. }\end{array}$ & & .842 & & \\
\hline $\begin{array}{l}\text { M20: Mesleğimle ilgili teknolojileri sürekli takip } \\
\text { ederim. }\end{array}$ & & .738 & & \\
\hline M23: Mesleğimle ilgili yazılımları kullanırım. & & .671 & & \\
\hline M18: Mesleğimle ilgili araştırmalar yaparım. & & .630 & & \\
\hline $\begin{array}{l}\text { M12: Mesleğime yönelik kendimi sürekli geliştir- } \\
\text { me gayreti içerisindeyim. }\end{array}$ & & .599 & & \\
\hline $\begin{array}{l}\text { M4: Bu mesleği neden seçtiğimin cevabını } \\
\text { biliyorum. }\end{array}$ & & & .725 & \\
\hline $\begin{array}{l}\text { M22: Mesleğimle ilgili yaptığım tercihlerin } \\
\text { farkındayım. }\end{array}$ & & & .691 & \\
\hline $\begin{array}{l}\text { M11: Meslek seçimimde kendi tercihlerim ön } \\
\text { plana çıktı. }\end{array}$ & & & .671 & \\
\hline M16: Mesleğimin gerekliliklerinin farkındayım. & & & .657 & \\
\hline $\begin{array}{l}\text { M17: Mesleğimin önemli olduğunu düşünüyo- } \\
\text { rum. }\end{array}$ & & & .538 & \\
\hline $\begin{array}{l}\text { M1: Başka kişilerin bu mesleği seçmesi için olum- } \\
\text { lu yorumlar yaparım. }\end{array}$ & & & & .841 \\
\hline $\begin{array}{l}\text { M2: Başka kişilerin bu mesleği seçmesine } \\
\text { sevinirim. }\end{array}$ & & & & .835 \\
\hline Faktör Özdeğerleri & 8.165 & 1.681 & 1.180 & 1.160 \\
\hline Açıklanan Varyans & 42.976 & 8.848 & 6.210 & 6.107 \\
\hline Toplam Açıklanan Varyansın & 42.976 & 51824 & 58.083 & 64.140 \\
\hline KMO Yeterlilik Ölçütü & & & 10 & \\
\hline Bartlett's Testi & & $\begin{array}{r}2207.38 \\
p=.\end{array}$ & $\begin{array}{l}89, \mathrm{sd}=1 \\
.000\end{array}$ & 171, \\
\hline Faktörlerin Cronbach's Alpha Katsayısı & .872 & .878 & .779 & .783 \\
\hline Tüm Değişkenlerin Cronbach's Alpha Katsayısı & & & 23 & \\
\hline
\end{tabular}

Tavşancıl, 2002). Dolayısıyla ölçek madde sayısı ve katılımcı sayısının faktör analizi çalışmaları için yeterli olduğu ifade edilebilir. Bu maddeler üzerinde yapılan açımlayıcı faktör analizi sonucunda dört madde, madde yüklerinin düşük olması nedeniyle çıkarılmıştır. Tablo 1'de ölçek maddelerine yönelik açımlayıcı faktör analizi sonuçları yer almıștır.

Tablo 1 incelendiğinde, geliştirilmesi planlanan ölçeğin dört faktörlü ve 19 maddeli yapısının uygun olduğu görülebilmektedir. Faktör analizinde temel bileșenler ve varimax döndürme yöntemleri kullanılmıştır. Faktör sayısının belirlenmesinde özdeğerlerin (eigen value) 1'den büyük olması dikkate alınmıştır. Yapılan faktör analizi sonucunda; 3, 7, 8, 13, 15, 19 ve 21. maddelerin Mesleki Hazır Bulunuşluk (MHB), 12, 14, 18, 20 ve 23. maddelerin Kendini Geliştirme (KG), 4, 11, 16, 17 ve 22. maddelerin Meslek Seçim Farkındalığı (MSF) ile 1 ve 2. maddelerin Mesleğini Başkalarına Önerme (MBÖ) boyutunda sınıflanabileceği belirlenmiştir. Ölçeğin 19 madde ve dört faktörlü yapısında toplam açıklanan varyansın \%64,14'ünü kapsamaktadır. Ölçeğe ait KMO değeri ,910 ve Cronbach's Alpha ,923 olarak tespit edilmiştir. Elde edilen KMO değerine göre örneklem büyüklügünün faktör analizi için "mükemmel" olduğu sonucuna ulaşılmıştır (Çokluk, Şekercioğlu ve Büyüköztürk, 2012). Cronbach's alpha değerinin .80'nin üzerinde olması ölçeğin güvenirliğinin yüksek olduğunu göstermektedir (Field, 2005).

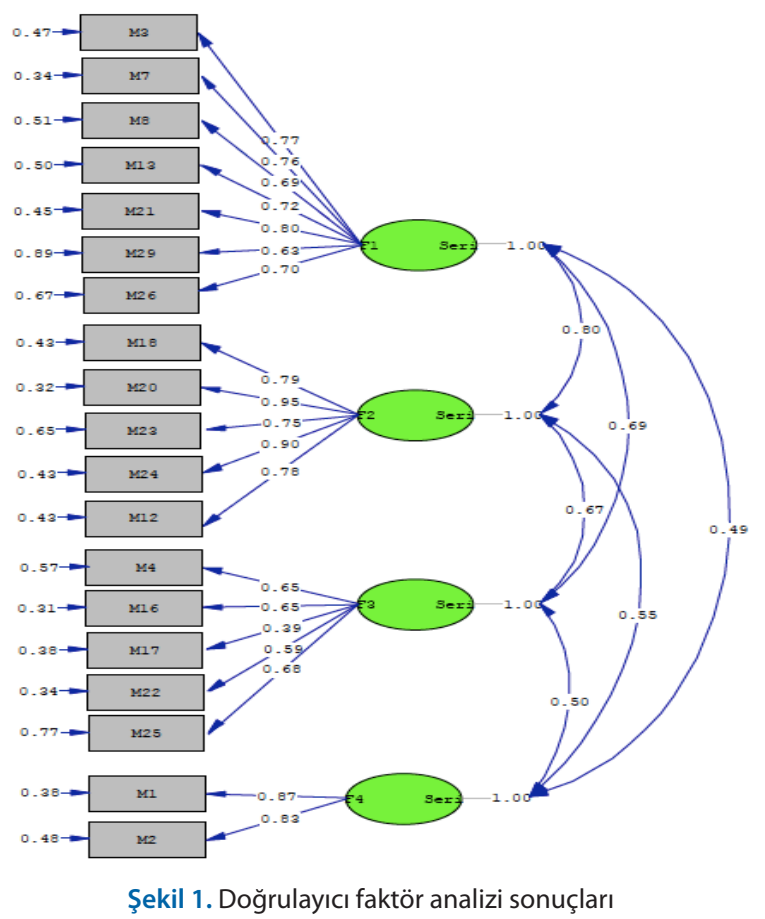

Açımlayıcı faktör analizi sonrasında 19 madde için Lisrel programı üzerinden ölçeğe yönelik doğrulayıcı faktör analizleri gerçekleştirilmiştir. $\mathrm{Bu}$ analizler sonucunda ölçek maddeleri ve faktörler arasındaki ilișki Șekil 1'de verilmiştir.

Şekil 1'e göre, ölçek maddeleri ve faktörler arasındaki ilişki düzeyi yeterli düzeydedir. Ayrıca ölçeğe yönelik 
Chi-Square değeri 235.99, serbestlik derecesi 137, p değeri 0.00 ve RMSEA değeri 0.057 olarak belirlenmiștir. X2/sd değerinin üçten küçük olması mükemmel düzeyde uyumun varlığı olarak ifade etmektedir (Schreiber vd., 2006). Bu sebeple ölçeğe ait bu değerin 1.72 olarak bulunması mükemmel düzeydeki uyumu göstermektedir. Ayrıca RMSEA değerinin 0.08 'den küçük olması uyumun iyi olduğunu göstermektedir (Çokluk ve diğ., 2012). Son olarak ölçeğe yönelik NFI değeri 0.96, CFI değeri 0.98, IFI değeri 0.98, RFI değeri 0.95, RMR değeri 0.054, SRMR değeri 0.051, GFI değeri 0.90 ve AGFI değeri 0.91 olarak ölçülmüştür. Bu sonuçlara göre model-veri uyumunun NFI, AGFI, NFI, CFI, IFI ve RFI değerleri için mükemmel olduğu, GFI RMR ve SRMR değerleri için kabul edilebilir düzeyde olduğu anlaşılmaktadır (Tabachnick ve Fidell, 2007).

\section{2. Ölçeğin Uygulanması}

Üniversite öğrencilerinin Mesleki İlgi Düzeylerini ölçmeye yönelik geliştirilen ölçek için uygulama sürecine geçilmiştir. Ölçeğin geliştirme aşamasındaki katılımcılardan farklı katılımcılar ile ölçek uygulama süreçleri yürütülmüştür. Bu kapsamda 296 katılımcı ölçeğin uygulanma aşamasında görüş bildirmiştir. Bu katılımcılara dair bazı bilgiler Tablo 2' de verilmiştir.

\begin{tabular}{|c|c|c|c|}
\hline Değişken & Özellik & $f$ & $\%$ \\
\hline \multirow{2}{*}{ Cinsiyet } & Erkek & 255 & 86.1 \\
\hline & Kadın & 41 & 13.9 \\
\hline \multirow{2}{*}{ Lise Mezuniyet Türü } & Meslek Lisesi & 212 & 71.6 \\
\hline & Genel (Anadolu) Lisesi & 84 & 28.4 \\
\hline \multirow{2}{*}{ Katılımcı Statüsü } & Öğrenci & 178 & 60.1 \\
\hline & Mezun & 118 & 39.9 \\
\hline \multirow{3}{*}{ Sinıf } & 1. sinıf & 75 & 25.3 \\
\hline & 2. sinıf & 103 & 34.8 \\
\hline & Mezun & 118 & 39.9 \\
\hline \multirow{3}{*}{ Yaş } & 17-19 Arası & 53 & 17.9 \\
\hline & $20-22$ arası & 183 & 61.8 \\
\hline & 23 ve üstü & 60 & 20.3 \\
\hline \multirow{3}{*}{$\begin{array}{c}\text { Programla İlgili Çalış- } \\
\text { ma Durumu }\end{array}$} & Çalışmıyorum & 162 & 54.7 \\
\hline & İlgisiz yerde çalışıyorum & 58 & 19.6 \\
\hline & İlgili yerde çalışıyorum & 76 & 25.7 \\
\hline \multirow{6}{*}{ Program } & Kontrol ve Otomasyon Tkn. & 86 & 29.1 \\
\hline & Elektronik Tkn. & 83 & 28.0 \\
\hline & Elektrik & 56 & 18.9 \\
\hline & Radyo ve Televizyon Tkn. & 37 & 12.5 \\
\hline & Elektronik Haberleşme Tkn. & 34 & 11.5 \\
\hline & Toplam & 296 & 100.0 \\
\hline
\end{tabular}

Tablo 2 incelendiğinde, cinsiyet değişkenine 255 (\%86.1) erkek, 41 (\%13.9) kadın; lise mezuniyet türüne göre 212 (\%71.6) meslek lisesi ve 84 (\%28.4) genel lise mezununun çalışmada yer aldığı görülmektedir. Çalışmadaki katılımcıların statüleri incelendiğinde 178'nin (\%60.1) öğrenci ve 118'inin (\%39.9) program mezunlarından oluştuğu anlaşılmaktadır. Katılımcılardan 75’i (\%25.3) birinci sınıf, 103'ü (\%34.8) ikinci sınıfta öğrenim gör- mektedir. Yaș değişkenine göre çalışmada 53'ü (\%17.9) 17-19, 183'ü (\%61.8) 20-22 arası ve 60'1 (\%20.3) 23 ve üstü yaşta katılımcılar bulunmaktadır. katılımcılardan 162'si (\%54.7) çalışmıyorken, 134'ü (\%45.3) bir işyerinde çalıştığını belirtmiştir. Bir işyerinde çalışan katılımcılardan 58'i (\%19.6) öğrenim gördüğü programla ilgisi olmayan bir işyerinde çalıştığını ifade etmişken, 76’sı (\%25.7) da programla ilgili bir işyerinde çalıștığını ifade emiştir. Son olarak katılımcilardan 86'sı (\% 29.1) Kontrol ve Otomasyon Teknolojisi, 83'ü (\%28.0) Elektronik Teknolojisi, 56’sı (\%28.9) Elektrik, 37'si (\%12.5) Radyo ve Televizyon Teknolojisi ve 34'ü (\%11.5) de Elektronik Haberleşme Teknolojisi Programında olduklarını ifade etmiştir.

\subsection{Uygulama Verilerinin Çözümlenmesi ve Yorumlanması}

Yapılan analizlerde dağılımın homojen olduğu durumlarda bağımsız gruplar t-testi ve tek yönlü varyans analizi kullanılmıştır. Tek yönlü varyans analizinde hangi gruplar arasında anlamlı fark olduğu Scheffe analizi sonuçlarına göre belirlenmiştir. Yapılan değerlendirmelerde katılımcıların mesleki ilgi düzeyleri Tablo 3'teki değerlere göre yorumlanmıştır.

Tablo 3. Ortalama Değerleri Yorumlamak için Kullanılan Puan Aralıkları ve Düzeyleri

\begin{tabular}{|c|c|}
\hline Değer Aralıkları & Düzeyler \\
\hline $1.00-1.80$ & Çok düşük (Kesinlikle katılmıyorum) \\
\hline $1.81-2.60$ & Düşük (Katılmıyorum) \\
\hline $2.61-3.40$ & Orta (Ne katılıyorum ne de katılmıyorum) \\
\hline $3.41-4.20$ & Yüksek (Katılıyorum) \\
\hline $4.21-5.00$ & Çok yüksek (Kesinlikle katılıyorum) \\
\hline
\end{tabular}

Tablo 3'teki değer aralıkları üzerinden, katılımcıların mesleki ilgi düzeyleri belirlenmiştir. Bu kapsamda, ölçeğin tamamı veya alt boyutları için katılımcıların ölçek maddelerine verdikleri yanıt ortalamasının $1.00-1.80$ arasında olması çok düşük, 1.81 - 2.60 arasında olması düşük, 2.61 - 3.40 arasında olması orta, 3.41 - 4.50 arasında olması yüksek ve 4.21 - 5.00 arasında olması ise çok yüksek şeklinde belirtilmiştir.

\section{BULGULAR}

Üniversite öğrencilerinin mesleki ilgi düzeylerini ölçmek amacıyla gerçekleştirilen çalışmada, elde edilen bulgular bu bölümde sunulmuştur. Bu kapsamda analizlere başlamadan önce, ölçeğe yönelik basıklık ve çarpıklık değerleri incelenmiştir. Mesleki İlgi (Mİ) Ölçeğine yönelik basıklık ve çarpıklık değerleri Tablo 4’te verilmiştir.

Tablo 4. Ölçeğe Yönelik Basıklık ve Çarpıklık Değerleri

\begin{tabular}{|c|c|c|c|}
\hline & $\mathrm{n}$ & Skewness & Kurtosis \\
\hline MHB & 296 & -0.902 & 0.688 \\
\hline KG & 296 & -0.472 & -0.347 \\
\hline MSF & 296 & -1.139 & 0.986 \\
\hline MBÖ & 296 & -0.837 & 0.065 \\
\hline Ölçeğin Tümü & 296 & -0.927 & 0.686 \\
\hline
\end{tabular}


Tablo 4'teki ölçeğin basıklık (Skewness) ve çarpıklık (Kurtosis) değerlerinin 0.986 ve -1.139 arasında değiștiği görülmektedir. Ölçeklerdeki normallik varsayımı için basıklık ve çarpıklık değerinin \pm 1.5 aralığında olması beklenmektedir (Tabachnick ve Fidell, 2007).

Çalışmada katılımcıların Mesleki İlgi Ölçeği ve alt boyutlarına yönelik düzeyleri analiz edilmiștir. Yapılan analizler sonucunda katılımcıların mesleki ilgi düzeyleri Tablo 5'te verilmiştir.

Tablo 5. Katılımcıların Mesleki İlgi Düzeyleri

\begin{tabular}{|c|c|c|c|c|}
\hline & $\mathrm{n}$ & $\overline{\boldsymbol{x}}$ & ss & Düzey \\
\hline MHB & 296 & 3.78 & .86 & Yüksek \\
\hline KG & 296 & 3.49 & .96 & Yüksek \\
\hline MSF & 296 & 4.02 & .94 & Yüksek \\
\hline MBÖ & 296 & 3.75 & 1.11 & Yüksek \\
\hline Ölçeğin Tümü & 296 & 3.76 & .81 & Yüksek \\
\hline
\end{tabular}

Tablo 5 incelendiğinde, katılımcıların mesleki ilgi düzeylerinin hem ölçeğin tamamında hem de alt boyutlarında yüksek olduğu görülebilmektedir.

Katılımcıların ifadeleri doğrultusunda cinsiyet değişkenine göre mesleki ilgilerine yönelik bağımsız gruplar t-testi analizi yapılmıştır. Yapılan analiz sonucunda elde edilen bulgular Tablo 6'da verilmiştir.

Tablo 6. Cinsiyet Değişkenine Göre Bağımsız Gruplar T Testi Sonuçları

\begin{tabular}{|c|c|c|c|c|c|c|c|}
\hline \multicolumn{9}{|c|}{} & Cinsiyet & $\mathrm{n}$ & $\overline{\boldsymbol{x}}$ & ss & $\mathrm{t}$ & sd & $\mathrm{p}$ \\
\hline \multirow{3}{*}{ MHB } & Erkek & 255 & 3.76 & .897 & -1.183 & 66.211 & .241 \\
\cline { 2 - 9 } & Kadın & 41 & 3.90 & .662 & & & \\
\hline \multirow{3}{*}{ KG } & Erkek & 255 & 3.46 & .987 & -1.263 & 294 & .208 \\
\cline { 2 - 9 } & Kadın & 41 & 3.66 & .793 & & & \\
\hline \multirow{2}{*}{ MSF } & Erkek & 255 & 3.98 & .960 & -1.968 & 294 & .050 \\
\cline { 2 - 9 } & Kadın & 41 & 4.29 & .803 & & & \\
\hline \multirow{3}{*}{ MBÖ } & Erkek & 255 & 3.73 & 1.145 & -.670 & 62.645 & .505 \\
\cline { 2 - 8 } & Kadın & 41 & 3.84 & .904 & & & \\
\hline \multirow{2}{*}{$\begin{array}{c}\text { Ölçeğin } \\
\text { Tümü }\end{array}$} & Erkek & 255 & 3.74 & .844 & -1.805 & 66.686 & .076 \\
\cline { 2 - 8 } & Kadın & 41 & 3.93 & .618 & & & \\
\hline
\end{tabular}

Tablo 6'ya göre ölçeğin tümü, KG, MHB ve MBÖ boyutlarında istatistiki olarak anlamlı bir farklılık tespit edilmemiştir. Ölçeğin sadece MSF boyutunda kadın öğrenciler lehine anlamlı farklılık tespit edilmiştir.

Katılımcıların mezun oldukları lise türleri değişkenine göre mesleki ilgilerine yönelik bağımsız gruplar t-testi analizi yapılmıştır. Yapılan analiz sonucunda elde edilen bulgular Tablo 7'de verilmiştir.

Tablo 7'deki verilere göre ölçeğin tümü ve MHB boyutunda anlamlı fark bulunmuştur. Bu fark meslek lisesinden mezun olanlar lehinedir. Ölçeğin KG, MSF ve MBÖ boyutlarında herhangi bir farklılık tespit edilmemiştir ( $\mathrm{p}>$.05).

Katılımcıların öğrenci veya programdan mezun olmuş olma durumları göz önünde bulundurularak statü değişkenine göre bağımsız gruplar t-testi analizi yapılmıştır.
Yapılan analiz sonucunda elde edilen bulgular Tablo 8'de verilmiştir.

Tablo 7. Lise Mezuniyet Değişkenine Göre Bağımsız Gruplar T Testi Sonuçları

\begin{tabular}{|c|c|c|c|c|c|c|c|}
\hline & & & & \multicolumn{3}{|c|}{ T testi } \\
\hline \multirow{2}{*}{ MHB } & Lise Mezuniyet & $\mathrm{n}$ & $\overline{\boldsymbol{x}}$ & $\mathrm{ss}$ & $\mathrm{t}$ & $\mathrm{sd}$ & $\mathrm{p}$ \\
\hline \multirow{3}{*}{ KG } & Meslek Lisesi & 212 & 3.89 & .856 & 3.498 & 294 & .001 \\
\hline & Genel Lise & 84 & 3.51 & .844 & & & \\
\hline \multirow{2}{*}{ MSF } & Meslek Lisesi & 212 & 3.53 & .947 & 1.112 & 294 & .267 \\
\cline { 2 - 8 } & Genel Lise & 84 & 3.39 & 1.005 & & & \\
\hline \multirow{2}{*}{ MBÖ } & Meslek Lisesi & 212 & 4.06 & .920 & 1.317 & 294 & .189 \\
\hline & Genel Lise & 84 & 3.90 & .999 & & & \\
\hline \multirow{2}{*}{ Ölçeğin Tümü } & Meslek Lisesi & 212 & 3.77 & 1.140 & .636 & 294 & .526 \\
\cline { 2 - 8 } & Genel Lise & 84 & 3.68 & 1.049 & & & \\
\hline & Meslek Lisesi & 212 & 3.83 & .807 & 2.189 & 294 & .029 \\
\hline & Genel Lise & 84 & 3.60 & .830 & & & \\
\hline
\end{tabular}

Tablo 8. Katılımcı Statüsü Değişkenine Göre Bağımsız Gruplar T Testi Sonuçları

\begin{tabular}{|c|c|c|c|c|c|c|c|}
\hline & & & & & \multicolumn{3}{|c|}{ T testi } \\
\hline & Statü & $\mathrm{n}$ & $\bar{x}$ & ss & $\mathrm{t}$ & sd & $\mathrm{p}$ \\
\hline \multirow{2}{*}{ MHB } & Öğrenci & 178 & 3.78 & .858 & -.082 & 294 & .935 \\
\hline & Mezun & 118 & 3.79 & .889 & & & \\
\hline \multirow{2}{*}{ KG } & Öğrenci & 178 & 3.43 & .925 & -1.226 & 294 & .221 \\
\hline & Mezun & 118 & 3.57 & 1.018 & & & \\
\hline \multirow{2}{*}{ MSF } & Öğrenci & 178 & 4.05 & .901 & .586 & 294 & .558 \\
\hline & Mezun & 118 & 3.98 & 1.010 & & & \\
\hline \multirow{2}{*}{ MBÖ } & Öğrenci & 178 & 3.77 & 1.049 & .465 & 225.767 & .642 \\
\hline & Mezun & 118 & 3.71 & 1.209 & & & \\
\hline \multirow{2}{*}{ Ölçeğin Tümü } & Öğrenci & 178 & 3.76 & .782 & -.163 & 294 & .871 \\
\hline & Mezun & 118 & 3.77 & .875 & & & \\
\hline
\end{tabular}

Tablo 8'deki veriler incelendiğinde, ölçeğin tamamı ve alt boyutlarına göre statü değişkenine göre anlamlı farklılık tespit edilmemiştir ( $\mathrm{p}>05)$.

Katılımcıların yaş değişkenine göre mesleki ilgilerine yönelik ANOVA testi yapılmıştır. Yapılan analiz sonucunda elde edilen bulgular Tablo 9' da verilmiştir.

Tablo 9'daki verilere göre katılımcıların yaş değişkenine göre istatistiki olarak anlamlı bir farklılık tespit edilmemiştir.

Çalışmada cevabı aranan sorular asında, katılımcıların öğrenim gördükleri programla ilişkili veya ilişkili olmayan bir işyerinde çalışması ve çalışmama durumları incelenmiștir. Bu değișkene göre mesleki ilgilerine yönelik ANOVA testi yapılmıștır. Yapılan analiz sonucunda elde edilen bulgular Tablo 10'da verilmiștir.

Tablo 10'a göre, katılımcıların öğrenim gördükleri programla ilgili veya ilgisiz bir işyerinde çalışma durumları arasında anlamlı farklılıklar tespit edilmiștir $(\mathrm{p}<.05)$. Bu farklılıkların hangi gruplar arasında olduğunu belirlemek amacıyla Scheffe testi uygulanmıștır. Bu sonuçlara göre, MHB ve Ölçeğin tamamı için meslekleriyle ilgili olmayan bir işyerinde çalışan katılımcılara göre mesleğiyle ilgili bir işyerinde çalışan gruplar lehine anlamlı farklılıklar tespit edilmiştir. Ayrıca ölçeğin KG boyutunda an- 
Tablo 9. Yaş Değişkenine Göre ANOVA Testi Sonuçları

\begin{tabular}{|c|c|c|c|c|c|c|c|c|c|}
\hline & & $\mathrm{n}$ & $\bar{x}$ & Var. Kay. & Kar. Top. & sd & Kar. Ort. & $\mathrm{F}$ & $\mathrm{p}$ \\
\hline \multirow{4}{*}{ MHB } & 17-19 Arası & 53 & 3.84 & G. arası & .642 & 2 & .321 & .423 & .656 \\
\hline & $20-22$ arası & 183 & 3.75 & G. içi & 222.321 & 293 & .759 & & \\
\hline & 23 ve üstü & 60 & 3.85 & Toplam & 222.963 & 295 & & & \\
\hline & Toplam & 296 & 3.78 & & & & & & \\
\hline \multirow{4}{*}{ KG } & 17-19 Arası & 53 & 3.51 & G. arası & 1.730 & 2 & .865 & .929 & .396 \\
\hline & $20-22$ arası & 183 & 3.43 & G. içi & 272.731 & 293 & .931 & & \\
\hline & 23 ve üstü & 60 & 3.63 & Toplam & 274.461 & 295 & & & \\
\hline & Toplam & 296 & 3.49 & & & & & & \\
\hline \multirow{4}{*}{ MSF } & 17-19 Arası & 53 & 4.12 & G. arası & .695 & 2 & .347 & .387 & .679 \\
\hline & $20-22$ arası & 183 & 3.99 & G. içi & 262.810 & 293 & .897 & & \\
\hline & 23 ve üstü & 60 & 4.02 & Toplam & 263.505 & 295 & & & \\
\hline & Toplam & 296 & 4.02 & & & & & & \\
\hline \multirow{4}{*}{ MBÖ } & 17-19 Arası & 53 & 3.85 & G. arası & .907 & 2 & .454 & .364 & .696 \\
\hline & $20-22$ arası & 183 & 3.74 & G. içi & 365.593 & 293 & 1.248 & & \\
\hline & 23 ve üstü & 60 & 3.68 & Toplam & 366.500 & 295 & & & \\
\hline & Toplam & 296 & 3.75 & & & & & & \\
\hline \multirow{4}{*}{$\begin{array}{c}\text { Ölçeğin } \\
\text { Tümü }\end{array}$} & 17-19 Arası & 53 & 3.83 & G. arası & .631 & 2 & .316 & .469 & .626 \\
\hline & $20-22$ arası & 183 & 3.73 & G. içi & 197.380 & 293 & .674 & & \\
\hline & 23 ve üstü & 60 & 3.82 & Toplam & 198.011 & 295 & & & \\
\hline & Toplam & 296 & 3.76 & & & & & & \\
\hline
\end{tabular}

Tablo 10. Programla İlgili Bir Alanda Çalışma Değişkenine Göre ANOVA Testi Sonuçları

\begin{tabular}{|c|c|c|c|c|c|c|c|c|c|c|}
\hline & & $\mathrm{n}$ & $\bar{x}$ & Var. Kay. & Kar. Top. & sd & Kar. Ort. & $\mathrm{F}$ & $\mathrm{p}$ & Fark \\
\hline \multirow{4}{*}{$\mathrm{MHB}$} & Çalışmıyor & 162 & 3.74 & G. arası & 5.758 & 2 & 2.879 & 3.884 & .022 & $2-3$ \\
\hline & İlgisiz yerde çalışıyor* & 58 & 3.61 & G. içi & 217.205 & 293 & .741 & & & \\
\hline & İlgili yerde çalışıyor & 76 & 4.00 & Toplam & 222.963 & 295 & & & & \\
\hline & Toplam & 296 & 3.78 & & & & & & & \\
\hline \multirow{4}{*}{ KG } & Çalışmıyor & 162 & 3.41 & G. arası & 6.869 & 2 & 3.435 & 3.761 & .024 & $1-3$ \\
\hline & İlgisiz yerde çalışıyor* & 58 & 3.37 & G. içi & 267.592 & 293 & .913 & & & \\
\hline & İlgili yerde çalışıyor & 76 & 3.75 & Toplam & 274.461 & 295 & & & & \\
\hline & Toplam & 296 & 3.49 & & & & & & & \\
\hline \multirow{4}{*}{ MSF } & Çalışmıyor & 162 & 4.01 & G. arası & 3.246 & 2 & 1.623 & 1.827 & .163 & \\
\hline & İlgisiz yerde çalışıyor* & 58 & 3.85 & G. içi & 260.259 & 293 & .888 & & & \\
\hline & İlgili yerde çalışıyor & 76 & 4.16 & Toplam & 263.505 & 295 & & & & \\
\hline & Toplam & 296 & 4.02 & & & & & & & \\
\hline \multirow{4}{*}{ MBÖ } & Çalışmıyor & 162 & 3.79 & G. arası & 5.395 & 2 & 2.698 & 2.189 & .114 & \\
\hline & İlgisiz yerde çalışıyor* & 58 & 3.48 & G. içi & 361.105 & 293 & 1.232 & & & \\
\hline & İlgili yerde çalışıyor & 76 & 3.86 & Toplam & 366.500 & 295 & & & & \\
\hline & Toplam & 296 & 3.75 & & & & & & & \\
\hline \multirow{4}{*}{$\begin{array}{l}\text { Ölçeğin } \\
\text { Tümü }\end{array}$} & Çalışmıyor & 162 & 3.73 & G. arası & 4.816 & 2 & 2.408 & 3.652 & .027 & $2-3$ \\
\hline & İlgisiz yerde çalışıyor* & 58 & 3.60 & G. içi & 193.195 & 293 & .659 & & & \\
\hline & İlgili yerde çalışıyor & 76 & 3.96 & Toplam & 198.011 & 295 & & & & \\
\hline & Toplam & 296 & 3.76 & & & & & & & \\
\hline \multicolumn{11}{|c|}{ * = Öğrenim gördüğü programla ilgisi olmayan bir yerde çalışıyor } \\
\hline
\end{tabular}

lamlı farklılık tespit edilmiştir. Bu fark çalışmayan katılımcılara göre, meslekleriyle ilgili bir işyerinde çalışan katılımcıların lehine anlamlı bir farklılık belirlenmiştir.

Katılımcıların öğrenim gördükleri program değişkenine göre mesleki ilgilerine yönelik ANOVA testi yapılmıştır. Yapılan analiz sonucunda elde edilen bulgular Tablo 11 'de verilmiştir.

Tablo 11'deki verilere göre öğrenim görülen program değişkeni açısından herhangi bir anlamlı farklılık tespit edilmemiştir ( $\mathrm{p}>05$ ).

\section{TARTIŞMA, SONUÇ VE ÖNERILER}

Ölçek geliştirme aşamasındaki sonuçlar göz önünde bulundurulduğunda, üniversite öğrencilerinin ve mezunlarının mesleki ilgi düzeylerini ölçmek amacıyla geliştirilen ölçeğin geçerli ve güvenilir olduğu ifade edilebilir. Bu kapsamda ölçeğe ait Mesleki Hazır Bulunuşluk, Kendini Geliştirme, Meslek Seçim Farkındalığı ve Mesleğini Başkalarına Önerme alt boyutlarının belirlenen boyutlardaki mesleki ilgileri ölçtüğü sonucuna ulaşılmıştır.

Çalışmada yer alan katılımcıların mesleki ilgi düzeyleri hem ölçeğin tamında hem de alt boyutlarında yüksek olarak belirlenmiştir. Bu tür ölçme araçları ile bireylerin mesleki ilgileri ön planda tutacak şekilde kendilerini 
Tablo 11. Program Değişkenine Göre ANOVA Testi Sonuçları

\begin{tabular}{|c|c|c|c|c|c|c|c|c|c|}
\hline & & $\mathrm{n}$ & $\bar{x}$ & Var. Kay. & Kar. Top. & sd & Kar. Ort. & $\mathrm{F}$ & $\mathrm{p}$ \\
\hline \multirow{6}{*}{ MHB } & Kontrol & 86 & 3.64 & G. arası & 4.395 & 4 & 1.099 & 1.463 & .214 \\
\hline & Elektronik & 83 & 3.80 & G. içi & 218.568 & 291 & .751 & & \\
\hline & Elektrik & 56 & 3.74 & Toplam & 222.963 & 295 & & & \\
\hline & Radyo TV & 37 & 3.99 & & & & & & \\
\hline & Haberleşme & 34 & 3.94 & & & & & & \\
\hline & Toplam & 296 & 3.78 & & & & & & \\
\hline \multirow{6}{*}{ KG } & Kontrol & 86 & 3.31 & G. arası & 5.833 & 4 & 1.458 & 1.580 & .180 \\
\hline & Elektronik & 83 & 3.60 & G. içi & 268.627 & 291 & .923 & & \\
\hline & Elektrik & 56 & 3.40 & Toplam & 274.461 & 295 & & & \\
\hline & Radyo TV & 37 & 3.62 & & & & & & \\
\hline & Haberleşme & 34 & 3.65 & & & & & & \\
\hline & Toplam & 296 & 3.49 & & & & & & \\
\hline \multirow{6}{*}{ MSF } & Kontrol & 86 & 3.96 & G. arası & 5.214 & 4 & 1.303 & 1.468 & .212 \\
\hline & Elektronik & 83 & 4.11 & G. içi & 258.291 & 291 & .888 & & \\
\hline & Elektrik & 56 & 3.80 & Toplam & 263.505 & 295 & & & \\
\hline & Radyo TV & 37 & 4.12 & & & & & & \\
\hline & Haberleşme & 34 & 4.20 & & & & & & \\
\hline & Toplam & 296 & 4.02 & & & & & & \\
\hline \multirow{6}{*}{ MBÖ } & Kontrol & 86 & 3.89 & G. arası & 7.899 & 4 & 1.975 & 1.602 & .174 \\
\hline & Elektronik & 83 & 3.73 & G. içi & 358.601 & 291 & 1.232 & & \\
\hline & Elektrik & 56 & 3.58 & Toplam & 366.500 & 295 & & & \\
\hline & Radyo TV & 37 & 3.48 & & & & & & \\
\hline & Haberleşme & 34 & 3.98 & & & & & & \\
\hline & Toplam & 296 & 3.75 & & & & & & \\
\hline \multirow{6}{*}{$\begin{array}{c}\text { Ölçeğin } \\
\text { Tümü }\end{array}$} & Kontrol & 86 & 3.66 & G. arası & 3.430 & 4 & .857 & 1.282 & .277 \\
\hline & Elektronik & 83 & 3.82 & G. içi & 194.582 & 291 & .669 & & \\
\hline & Elektrik & 56 & 3.65 & Toplam & 198.011 & 295 & & & \\
\hline & Radyo TV & 37 & 3.88 & & & & & & \\
\hline & Haberleşme & 34 & 3.94 & & & & & & \\
\hline & Toplam & 296 & 3.76 & & & & & & \\
\hline
\end{tabular}

daha iyi tanımaları ve ilgi duydukları alana yönlenmeleri sağlanabilir (Toker, 2017). Üniversite öğrencilerinin meslek seçiminde etkili olan etmenlerin başında mesleki ilgi ve bireylerin yetenekleri gelmektedir (Şeker ve Çapri, 2020; Korkut-Owen, Kepir, Özdemir, Ulaş ve Yılmaz, 2012). Mesleki ilgideki kararlılık üniversite çağındaki yıllarda en yüksek seviyeye ulaşır (Low, Yoon, Roberts ve Rounds, 2005). Bu sonuçla, öğrencilerin öğrenim gördükleri mesleğe yönelik programı, mesleki ilgilerini ön planda tutarak tercih ettiği ifade edilebilir. Meslek seçiminde bireylerin ilgi, yetenek ve beklentilerini dikkate alarak tercih yapması bu nedenle önemlidir (Polatcı ve Gültekin, 2019). Çünkü bu aşamadaki kararlar, bireylerin yaşamlarının tamamını etkileyebilmektedir. Diğer bir ifade ile bireysel ilgiler eğitim ve kariyer hakkında karar vermede en önemli etken olarak görülebilir (Tang, 2009). Aynı zamanda mesleki ilgilerin bireyde itici güç veya motivasyon kaynağı olduğu ön planda tutulmalıdır (Rounds ve $\mathrm{Su}, 2014)$. Mesleki ilgisi yüksek bireylerin motivasyon düzeylerinin yüksek olduğu ve bu motivasyonun bireylerde itici güç olduğu ifade edilebilir. Elde edilen sonuçların üniversitelerin değerlendirilmesinde dikkate alınan öğrenci memnuniyet algılarına (Aydemir, 2016) yardımcı olabileceği ifade edilebilir.

Cinsiyete göre Meslek Seçim Farkındalığı boyutunda kadınlar lehine anlamlılık tespit edilmiştir. Mesleki ilgi süreçlerinde cinsiyete bağlı beklentiler üzerinden kimlikler oluşmasında okul, aile ve iş gibi çevresel etkiler rol almaktadır (Low ve Rounds, 2007). Cinsiyete göre diğer boyutlarda ve ölçeğin tamamında farklılık olmaması, çalışmada yer alan mesleki programların cinsiyet kimliği olmadığı şeklinde yorumlanabilir. Lise mezuniyet türleri incelendiğinde, meslek lisesi mezunları lehine ölçeğin Mesleki Hazır Bulunuşluk ve tamamı için anlamlı farklılık tespit edilmiştir. Mesleki ilgiler, bazen diğer ilgileri de olumlu şekilde etkileyebilmektedir (Perera ve McIlveen, 2018). Bu sonucun elde edilmesinde, meslek lisesi mezunların önceki yaşantıları etkisi olduğu ifade edilebilir. Meslek lisesi mezunlarının staj deneyimleri mesleki ilgilerini olumlu şekilde etkileyebilmektedir (Neuenschwander ve diğ., 2018). Meslek lisesi mezunlarının meslekleriyle daha fazla zaman geçirmiş olması mesleki ilgilerinin daha yüksek olmasının etkili olduğu şeklinde yorumlanabilir. Çünkü ilginin oluşmasında yaşantıların etkisi oldukça yüksektir (Özgüven, 2000).

Yapılan analizlerde, bireylerin çalışma durumları ve çalışıyorlarsa öğrenim gördükleri programla ilgili alanda çalışmaları incelenmiştir. Yapılan incelemede ölçeğin tamamı, Mesleki Hazır Bulunuşluk ve Kendini Geliştirme alt boyutlarında anlamlı ilişkiler tespit edilmiştir. Bu sonuçlar mesleğiyle ilgili bir yerde çalışan bireyler lehinedir. İlginin, bireylerin yaşantılarını etkileyen bir kavram 
olduğu (Ion, Nye ve Iliescu, 2019; Yaman, Gerçek ve Soran, 2008) göz önüne alındığında, meslekleriyle ilgili bir işyerinde çalışmalarının olumlu etkisi öne çıkmaktadır. Ayrıca mesleki ilginin mesleki seçim sürecini etkilediği (Baker, Larson ve Seipel, 2019; Larson, 2012) ve bireylerin belirli faaliyetlere ve çevrelere yakınlaşmalarında veya onlardan uzaklaşmalarında yönlendirici olduğu (Larson ve diğ., 2014) unutulmamalıdır. Çünkü bireyler mesleki ilgilerini göz önünde bulundurarak çevreleri hakkında karar verebilmektedir. Aynı zamanda bireylerin mesleki ilgileri üzerinden, istihdam olmaları hakkında tahminler yürütülmektedir (Van Iddekinge ve diğ., 2011). Bunun temel nedeni olarak, ilgi düzeyi yüksek bireylerce mesleğin icra edilmesinin yapılacak işin niteliğini arttırabileceği görüşü ifade edilebilir (Yaman, Gerçek ve Soran, 2008). Bu sayede istihdam olacak bireyler ve işverenlerdeki memnuniyet de artabilir. Öğrencilerdeki memnuniyet değișimi, üniversite öğretim elemanlarının daha kapsamlı bir şekilde değerlendirilmesinde kullanılabilecek bir ölçüt olabilir (Aydemir, 2019).

Üniversite öğrencisi ve mezun katılımcılar arasında yapılan incelemede mesleki ilgi boyutlarında bir farklılık tespit edilememiştir. Benzer şekilde katılımcıların yaş grupları ve öğrenim gördükleri programlar arasında da farklılık tespit edilememiştir. Bu sonuçlar, bireylerin tercihlerinin mesleki ilgileri çerçevesinde şekillendiği ve bu ilginin yaşa ve programa bağlı olmadan mezuniyet sonrasına da yansıdığı şeklinde ifade edilebilir. Dolayısıyla bireylerin mesleki ilgi düzeylerinin zamanla belirgin bir șekilde farklılaşmadığı ifade edilebilir. Mesleki ilgi ve öz-yeterlik algıları, meslek seçiminde en önemli faktörler olarak öne çıkmaktadır (Baker, Larson ve Seipel, 2019; Larson, 2012). Çalışmadaki katılımcıların mesleki ilgi ve öz-yeterlik algılarının mesleki ilgileri çerçevesinde geliştiği ifade edilebilir. Aynı zamanda mesleki ilgiler, bireyin bir mesleğe yakınlaşmasında veya uzaklaşmasında yönlendiricidir (Larson ve diğ., 2014). Buradan hareketle, mesleki ilginin meslek tercihinde etkili olduğu ve bu ilginin bireyde devamlılığı söz konusudur. Ayrıca bireylerdeki mesleki ilgiyi arttırmak amacıyla alternatif yöntemlerin kullanılması sağlanabilir (Genç ve Aydemir, 2015).

Çalışmadan elde edilen sonuçlara bağlı olarak bir takım öneriler aşağıda sunulmuştur. Üniversite ve öğrenim görülecek program için, bireylerin potansiyel mesleki ilgilerini de dikkate alarak yaptıkları tercihler zamanla değișebilmektedir. Bu değişimin en önemli nedenleri arasında bireylerin öğrenimleri süresince yaşadıkları deneyimleridir. Bireylerin bu değişimler sonucunda, mesleki ilgilerindeki olası değişimlerinin takip edilmesi ihtiyacı oluşabilmektedir. Bu değişimlerde bireylere mesleki rehberlik hizmetinin verilmesi yerinde olacaktır. Bu kapsamda mesleki ilgi ölçeğinin farklı zamanlarda bireylere uygulanması sağlanabilir. Yapılan uygulamalar sonucunda, mesleki ilgi düzeyleri düşük çıan öğrencilere başka öğrenim programlarına geçme imkanı sağlanabilir. Fakat bu program geçişleri arasında şimdiki program ile yeni programın birbirine yakın olması dikkate alınmalıdır. Çünkü öğrencinin kendisine yabancı bir programda öğrenim görmesi mesleğe uyum sağlama noktasında sorunlara neden olabilir. Mesleki ilgi düzeyi ve bireylerin mesleki yeterlikleri arasındaki ilişki hakkında çalışmalar yapılabilir. Bireylerin mesleki ilgilerini belirlemek amacıyla geliştirilen ölçeğin farklı birimdeki katılımcılara uygulanması sağlanabilir. Bu sayede ilgili birimdeki öğrencilerin mesleki ilgi düzeyleri ortaya çıkarılabilir.

\section{KAYNAKÇA}

Atli, A., \& Keldal, G. (2017). Mesleki kişilik tipleri envanterinin geliştirilmesi. Eskişehir Osmangazi Üniversitesi Sosyal Bilimler Dergisi, 18(1), 73-93.

Aydemir, E. (2019). Akademik Personel Performans Değerlendirmesinde Bir Karar Destek Sistemi Önerisi. Bilişim Teknolojileri Dergisi, 12(2), 131-140.

Aydemir, E. (2016). Öğrenci Memnuniyeti Açısından Üniversiteler Arası Sıralamada Yeni Bir Sistem Önerisi. Yükseköğretim Dergisi, 6(3): 124-137.

Baker, D. F., Larson, L. M., \& Seipel, M. T. (2019). Relation of reinforcement sensitivity on vocational interest and self-efficacy. Journal of Career Assessment, 27(2), 230-245.

Bergmann, C., \& Eder, F. (2005). AIST-R. Allgemeiner-Interessen-Struktur-Test mit Umwelt-Struktur-Test (UST-R). [GIST-R. General interest structure test with environmental structure test (EST-R)] -Revision. Göttingen, Germany: Beltz Test $\mathrm{GmbH}$.

Büyüköztürk, Ş., Çakmak, E.K., Akgün, Ö.E., Karadeniz, Ş. ve Demirel, F. (2008). Bilimsel Araştırma Yöntemleri. Ankara: Pegem.

Büyüköztürk, Ş. (2002). Faktör analizi: Temel kavramlar ve ölçek geliştirmede kullanımı. Kuram Ve Uygulamada Eğitim Yönetimi, 32(32), 470-483.

Comrey, A. L. (1988). Factor-analytic methods of scale development in personality and clinical psychology. Journal of Consulting And Clinical Psychology, 56(5), 754.

Çokluk, Ö., Şekercioğlu, G. ve Büyüköztürk, Ş. (2012). Sosyal Bilimler İçin Çok Değişkenli İstatistik: SPSS ve Lisrel Uygulamaları. Pegem Akademi Yayıncılık, Ankara.

Dikmen, M. ve Tuncer, M. (2018). Öğretmenlik Mesleğine Yönelik Tutumların Çeşitli Değişkenlere Göre Değerlendirilmesi. Harran Maarif Dergisi, 3(1), 24-38.

Donnay, D. A. C., Morris, M. L., Schaubhut, N. A., \& Thompson, R. C. (2005). Strong Interest Inventory manual: Research, development, and strategies for interpretation. Mountain View, CA: CPP.

Elsworth, G. R., Harvey-Beavis, A., Ainley, J., \& Fabris, S. (1999). Generic interests and school subject choice. Educational Research and Evaluation, 5(3), 290-318.

Field, A. (2005). Discovering Statistics Using SPSS. London: Sage.

Genç, Z. ve Aydemir, E. (2015). An alternative evaluation: online puzzle as a course-end activity. Interactive Technology and Smart Education, 12(3), 169-182.

Ion, A., Nye, C. D., \& Iliescu, D. (2019). Age and gender differences in the variability of vocational interests. Journal of Career Assessment, 27(1), 97-113. 
Korkut-Owen, F. K., Kepir, D., Özdemir, S., Ulaş, Ö. ve Yılmaz, O. (2012). Üniversite öğrencilerinin bölüm seçme nedenleri. Mersin Üniversitesi Eğitim Fakültesi Dergisi, 8(3), 135-151

Larson, L. M. (2012). Worklife across the lifespan. In J. I. Hansen \& E. Altmeir (Eds.), Handbook of counseling psychology (pp. 128-178). Oxford, England: Oxford University Press.

Larson, L. M., Pesch, K. M., Bonitz, V. S., Wu, T. F., \& Werbel, J. D. (2014). Graduating with a science major: The roles of first-year science interests and educational aspirations. Journal of Career Assessment, 22(3), 479-488. https://doi. org/10.1177/1069072713498680.

Low, K. S. D., \& Rounds, J. (2007). Interest change and continuity from early adolescence to middle adulthood. International Journal of Educational and Vocational Guidance, 7, 23-36. doi:10.1007/s10775-006-9110-4

Low, K. S. D., Yoon, M., Roberts, B. W., \& Rounds, J. (2005). The stability of vocational interests from early adolescence to middle adulthood: A quantitative review of longitudinal studies. Psychological Bulletin, 131, 713-737. doi:10.1037/0033-2909.131.5.713

Neuenschwander, M. P., Hofmann, J., Jüttler, A., \& Schumann, S. (2018). Professional desires and career decisions: Effects of professional interests, role models, and internship in lower secondary school. International Journal For Research In Vocational Education And Training, 5(3), 226-243.

Ott-Holland, C. J., Huang, J. L., Ryan, A. M., Elizondo, F., \& Wadlington, P. L. (2013). Culture and vocational interests: The moderating role of collectivism and gender egalitarianism. Journal of Counseling Psychology, 60, 569-581. doi:10.1037/ a0033587

Özgüven, İ. E. (2000). Psikolojik Testler. Ankara: PDREM Yayınları.

Perera, H. N., \& Mcllveen, P. (2018). Vocational interest profiles: Profile replicability and relations with the STEM major choice and the Big-Five. Journal of Vocational Behavior, 106, 84-100.

Pohlhausen, A. (2005). Entwicklung und Evaluation eines Studieninteressenfragebogens für Offizierbewerber bei der Offizierprüfzentrale der Bundeswehr, Dissertation, TU Dortmund.

Polatcı, S., \& Gültekin, Z. (2019). Meslek yüksekokulunda okuyorum seçtiğim mesleğe uygun muyum? Mehmet Akif Ersoy Üniversitesi Sosyal Bilimler Enstitüsü Dergisi, 9(21), 384-396.

Rounds, J., \& Su, R. (2014). The nature and power of interests. Current Directions in Psychological Science, 23, 98-103. doi:10.1177/0963721414522812

Schreiber, J. B., Nora, A., Stage, F. K., Barlow, E. A., \& King, J. (2006). Reporting structural equation modeling and confirmatory factor analysis results: A review. The Journal of educational research, 99(6), 323-338.

Sekiguchi, T. (2004). Person-Organization Fit And Person-Job Fit in Employee Selection: A Review Of The Literatüre. Osaka Keidai Ronshu, 54(6), 179-196.

Sheu, H. B., Lent, R. W., Brown, S. D., Miller, M. J., Hennessy, K. D., \& Duffy, R. D. (2010). Testing the choice model of social cognitive career theory across Holland themes: A meta-analytic path analysis. Journal of Vocational Behavior, 76(2), 252-264.
Su, R., Rounds, J., \& Armstrong, P. I. (2009). Men and things, women and people: A meta-analysis of sex differences in interests. Psychological Bulletin, 135, 859-884. doi:10.1016/j. jvb.2003.11.002

Şeker, G. ve Çapri, B. (2020). Eğitim Fakültesi Öğrencilerinin Meslek Seçiminde Etkili Olan Faktörler. Mersin Üniversitesi Eğitim Fakültesi Dergisi, 16(3), 651-663.

Tabachnick, B. G., \& Fidell, L. S. (2007). Using multivariate statistics (5th ed.). Boston: Allyn and Bacon.

Tang, M. (2009). Examining the application of Holland's theory to vocational interests and choices of Chinese college students. Journal of Career Assessment, 17(1), 86-98. https:// doi.org/10.1177/1069072708325743.

Tavşancıl, E. (2002). Tutumların ölçülmesi ve SPSS ile veri analizi. Nobel Yayıncilık, Ankara.

Toker, Y. (2017). Karmaşık FTMM alanlarına ilgilerin öncül değişkenler ve mesleki uyum ölçütleri arasında aracı rolü. Ankara Üniversitesi Dil ve Tarih-Coğrafya Fakültesi Dergisi, 57(2), 1103-1126.

Tracey, T. J. G., Robbins, S. B., \& Hofsess, C. D. (2005). Stability and change in interests: A longitudinal study of adolescents from grades 8 to 12. Journal of Vocational Behavior, 66, 1-25. doi:10.1016/j.jvb.2003.11.002

Van Iddekinge, C. H., Roth, P. L., Putka, D. J., \& Lanivich, S. E. (2011). Are you interested? A meta-analysis of relations between vocational interests and employee performance and turnover. Journal of Applied Psychology, 96, 1167-1194. doi:10.1037/a0024343

Yaman, M., Gerçek, C., \& Soran, H. (2008). Biyoloji öğretmen adaylarının mesleki ilgilerinin farklı değişkenler açısından incelenmesi. Hacettepe Üniversitesi Eğitim Fakültesi Dergisi, 35(35), 351-361. 